\title{
INVERSIONES EXTRANJERAS Y DERECHOS HUMANOS: ENTRE LA PERMANENCIA Y EL CAMBIO
}

\section{INVESTIMENTOS ESTRANGEIROS E DIREITOS HUMANOS: ENTRE A PERMANENCIA E A MUDANÇA}

Juan Pablo Bohoslavsky
Juan Bautista Justo

Resumen: El derecho internacional condiciona de modo creciente el funcionamiento de los países, al mismo tiempo que presenta problemas de fragmentación que exponen a las autoridades nacionales a señales contradictorias, sobre todo cuando sus diversos subsistemas persiguen objetivos susceptibles de entrar en colisión. Eso es lo que sucede con el régimen de protección de inversiones extranjeras - cuyo funcionamiento actual tiene por objetivo asegurar la estabilidad del entorno jurídico $y$ económico de esas inversiones - frente al régimen de tutela de los derechos humanos - que implica asumir el deber de transformar muchos aspectos de ese mismo entorno para alcanzar las metas de satisfacción de los derechos consagrados en los tratados, en especial en aquellos países más alejados de las condiciones mínimas de disfrute de tales derechos-. Frente a esa potencial tensión, este artículo analiza si el avance en la efectivización de los derechos humanos puede ser interpretado como una violación a los estándares de los tratados bilaterales de protección de inversiones (TBIs), y en su caso, con qué alcance. Para ello estudia tres aspectos del régimen de tutela de los inversores que han dado lugar a reclamos frente a medidas regulatorias que modifican el clima de negocios: trato justo $y$ equitativo, expropiación y cláusulas de estabilización. Por último, y a la luz de la discusión planteada, se estudia la exigencia del consentimiento previo, libre e informado de las comunidades indígenas para el desarrollo de proyectos productivos en sus territorios como una hipótesis concreta en la que la tensión queda puesta de manifiesto, sugiriendo algunas pautas para su abordaje.

\footnotetext{
* Experto Independiente sobre Deuda Externa y Derechos Humanos de la ONU. E-mail: juanpablobohos@gmail.com

** Docente de Derecho Administrativo, Universidad Nacional del Comahue, Argentina. E-mail: justo.juanbautista@gmail.com

Las opiniones y conclusiones desarrolladas en este capítulo sólo reflejan las de sus autores y de ninguna manera las de las instituciones a las cuales están afiliados.
} 
Resumo: $O$ direito internacional condicional de maneira crescente o funcionamento dos países ao mesmo tempo que apresenta problemas de fragmentação que expõem as autoridades nacionais a sinais contraditórios, sobretudo quando seus diversos sistemas perseguem objetivos susceptíveis de entrar em colisão. Isso é o que acontece com o regime de proteção de investimentos estrangeiros - cujo funcionamento atual tem por objetivo assegurar a estabilidade do entorno jurídico e econômico desses investimentos - frente ao regime de tutela dos direitos humanos - que implica assumir o dever de transformar muitos aspectos desse mesmo entorno para alcançar as metas de satisfação dos direitos consagrados nos tratados, em especial naqueles países mais distantes das condições mínimas de gozo desses direitos. Frente a essa potencial tensão, este artigo analisa se o avanço na efetivação dos direitos humanos pode ser interpretado como uma violação dos preceitos dos tratados bilaterais de proteção de investimentos (TBIs) e, nesse caso, com que alcance. Para tanto, estuda três aspectos do regime de tutela de investidores que deram lugar a reclamações relacionadas a medidas regulatórias que modificam o ambiente de negócios: tratamento justo e equânime, expropriação e cláusulas de estabilização. Por último, e à luz da discussão proposta, estuda-se a exigência do consentimento prévio, livre e informado das comunidades indígenas para o desenvolvimento de projetos produtivos em seus territórios como uma hipótese concreta, na qual essa tensão se manifesta, sugerindo algumas pautas para a sua abordagem.

Palabras clave: Inversiones extranjeras, Tratados bilaterales de inversión, Derechos humanos, Derecho internacional, Comunidades indígenas, Obligaciones internacionales contradictorias

Palavras-chave: Investimentos estrangeiros, Tratados bilaterais de investimentos, Direitos humanos, Direito internacional, Comunidades indígenas, Obrigações internacionais contraditórias

\section{PRESENTACIÓN}

El desempeño de las autoridades públicas de los países latinoamericanos (así como el de países de otras regiones) se encuentra crecientemente condicionado por diferentes regímenes internacionales que imponen a los Estados pautas de comportamiento cada vez más intrusivas. Los estándares mínimos de protección que emanan de las normas internacionales y de la interpretación que de ellas hacen sus órganos de aplicación, entrañan la adecuación de las prácticas internas de cualquier naturaleza a una red de garantías que no resulta discutible por los Estados ni por sus divisiones políticas una vez que han prestado su 
consentimiento a ellas. En estos casos, es ineludible la adaptación de los procedimientos, instituciones y usos nacionales para mantenerse dentro de las fronteras de cumplimiento de los compromisos internacionales.

Dentro de esta dinámica de globalización de los ordenamientos domésticos, el fenómeno de fragmentación del derecho internacional hace que las autoridades nacionales puedan verse expuestas a señales contradictorias, sobre todo cuando los diversos subsistemas persiguen objetivos susceptibles de entrar en colisión. Eso es lo que sucede con el régimen de protección de inversiones -cuyo funcionamiento actual parece tener por meta asegurar la estabilidad del entorno jurídico y económico de las inversiones extranjeras- frente al régimen de tutela de los derechos humanos -que implica asumir el deber de transformar muchos aspectos de ese entorno para alcanzar las metas de satisfacción de los derechos consagrados en los tratados, en especial en aquellos países más alejados de las condiciones mínimas de disfrute de tales derechos-.

Como producto de esa diversidad de objetivos - estabilidad versus transformación- la sujeción simultánea a estos regímenes genera con frecuencia un dilema a los Estados, que se vuelve tangible cuando se ven sometidos a reclamos desde los dos frentes: o bien se los responsabiliza por no adoptar las medidas que le exigen los pactos de derechos humanos, o bien se lo hace por adoptar esas medidas y afectar -con ello- los intereses de los inversores.

Frente a esa potencial tensión, analizaremos aquí si el avance en la efectivización de los derechos humanos puede ser interpretado como una violación a los estándares de los tratados bilaterales de protección de inversiones (TBIs), y en su caso, con qué alcance. Para ello estudiaremos tres aspectos del régimen de tutela de los inversores que han dado lugar a reclamos frente a medidas regulatorias que modifican el clima de negocios: trato justo y equitativo, expropiación y cláusulas de estabilización. Por último plantearemos a la exigencia del consentimiento previo, libre e informado de las comunidades indígenas para el desarrollo de proyectos productivos en sus territorios como una hipótesis concreta en la que la tensión queda puesta de manifiesto, sugiriendo algunas pautas para su abordaje.

\section{LOS DOS MODELOS NORMATIVOSENJUEGO.ESTABILIDAD VS. TRANSFORMACIÓN}

La mayoría de los países de la región se encuentran sometidos al mismo tiempo a dos conjuntos de reglas internacionales que los condicionan; uno tiene por objeto proteger a los inversores extranjeros y se sustenta en la amplia red de TBIs amparados en la Convención del Centro Internacional de Arreglo de Diferencias Relativas a Inversiones 
(CIADI) aprobada en 1965; el otro se orienta a la protección de los derechos humanos y tiene su anclaje regional en la Convención Americana sobre Derechos Humanos (CADH) de 1969, instrumento que se complementa en la mayoría de los países con el sometimiento al Pacto Internacional de Derechos Económicos, Sociales y Culturales (PIDESC) de 1966, de especial interés para esta temática.

\subsection{El régimen de los TBIs. Protección contra el cambio}

La estructura de protección de los inversores -integrada por la Convención del CIADI y la red de TBIs que en forma vertiginosa fueron firmando los países en las últimas décadas, pero también por diferentes tratados multilaterales de libre comercio- se asienta en dos bases: la primera procesal, la segunda sustancial.

a) Desde una perspectiva procesal, esto es, desde los mecanismos que se aplican para resolver una disputa entre un inversor y el Estado que lo aloja, el sistema presenta los siguientes lineamientos:

i. El TBI se aplica a todas las inversiones extranjeras salvo las que estén expresamente excluidas, sin importar el rol estratégico o la relevancia nacional que pueda tener la actividad en la que ellas se insertan (por ejemplo, servicios públicos, salud pública). De esa forma, sectores claves de la economía quedan sujetos a un modelo de internacionalización del derecho que consiste básicamente en extrapolar las reglas del arbitraje privado al campo del derecho público;

ii. Cuando los inversores (o un socio minoritario de ellos) se sienten afectados por alguna decisión del Estado que involucra cualquier aspecto de su inversión, pueden demandarlo directamente (sin necesidad de recorrer antes ningún camino interno) ${ }^{1}$ por fuera de sus jueces y ante foros arbitrales en los cuales el poder político y de voto está concentrado en los principales países exportadores de capitales (vg. el Banco Mundial);

iii. A través de las "cláusulas paraguas" las infracciones a compromisos contractuales por parte del Estado pueden ser elevadas a violaciones de sus obligaciones internacionales, con lo cual cualquier aspecto de un vínculo con el prestador de un servicio estatal puede terminar siendo dirimido en la jurisdicción del CIADI²;

1 A diferencia de lo que sucede con los pactos de derechos humanos, la jurisdicción internacional prevista en los TBIs es principal y no subsidiaria; es decir que desplaza -y no complementa- la labor de los jueces locales (MONTT, Santiago. "What international investment law and Latin America can and should demand from each other. Updating the Bello/Calvo doctrine in the BIT generation”. En: AA.VV. (ed). El Nuevo Derecho Administrativo Global en América Latina. Buenos Aires, 2009.

2 El alcance concreto de esta cláusula es objeto de un debate no concluido. Tienden a 
iv. Los árbitros a los cuales llega la disputa pueden revisar la conducta de cualquier rama del Estado y desplazar del análisis al derecho nacional, aplicando los criterios del TBI;

v. La decisión que adopten esos árbitros tiene un marco de revisión sumamente limitado a nivel internacional ${ }^{3}$ y directamente nulo a nivel local ${ }^{4}$. Los jueces nacionales no pueden controlar el laudo y deben ponerlo en práctica (por ejemplo embargando bienes del Estado) como si fuera una sentencia pasada en autoridad de cosa juzgada.

b) En ese sistema de resolución de controversias que -como vemosse caracteriza por sustraer absolutamente el conflicto de la esfera del país receptor, se aplican una serie de principios sustanciales de protección a los inversores que se fijan en la red de TBIs. En general, se prohíben allí conductas que infrinjan estándares tales como el tratamiento justo y equitativo, de tratamiento nacional y nación más favorecida, o la prohibición de expropiar directa o indirectamente la inversión sin la correspondiente compensación.

Ahora bien, el problema es que los TBIs establecen esos estándares con un alto grado de indeterminación, sin detallar con precisión los derechos y obligaciones de las partes ${ }^{5}$. Ello hace que sean los árbitros

expandir su alcance -y por ende a someter al CIADI discusiones contractuales laudos como Compañía de Aguas del Aconquija S.A. y Vivendi Universal v. Argentina (2002, Caso CIADI No ARB/97/3, Decisión sobre Anulación); SGS Société Générale de Surveillance S.A. v. Filipinas (2004, Caso CIADI No ARB/02/6); Astaldi S.p.A. v. Honduras (2010, Caso CIADI No ARB/ O7/32). Una perspectiva diferente, encaminada a limitar los reclamos susceptibles de llegar a los árbitros, ofrecen los casos Azinian v. México (1999, Caso CIADI No ARB.F./97/2); SGS Société Générale de Surveillance S.A. v. Pakistán (2003, Caso CIADI No ARB/01/13, Decisión sobre Jurisdicción); El Paso Energy International Company v. Argentina (2006, Caso CIADI No ARB/03/15, Decisión sobre Jurisdicción); Gustav F W Hamester GmbH \& Co KG v. Ghana (2010, Caso CIADI No ARB/07/24).

$3 \mathrm{El}$ art. 52 del Convenio CIADI solo permite la anulación del laudo bajo las siguientes causales: a) que el Tribunal se hubiere constituido incorrectamente; b) que el Tribunal se hubiere extralimitado manifiestamente en sus facultades; c) que hubiere habido corrupción de algún miembro del Tribunal; d) que hubiere quebrantamiento grave de una norma de procedimiento; o e) que no se hubieren expresado en el laudo los motivos en que se funde. Es decir que no se prevén a los errores jurídicos de la decisión como justificativo para su revocación.

$4 \mathrm{El}$ art. 54 del Convenio CIADI establece que "Todo Estado Contratante reconocerá al laudo dictado conforme a este Convenio carácter obligatorio y hará ejecutar dentro de sus territorios las obligaciones pecuniarias impuestas por el laudo como si se tratare de una sentencia firme dictada por un tribunal existente en dicho Estado. El Estado Contratante que se rija por una constitución federal podrá hacer que se ejecuten los laudos a través de sus tribunales federales y podrá disponer que dichos tribunales reconozcan al laudo la misma eficacia que a las sentencias firmes dictadas por los tribunales de cualquiera de los estados que lo integran." Explorando la posibilidad de ejercer el control de convencionalidad sobre los laudos véase BOHOSLAVSKY, Juan Pablo y JUSTO, Juan Bautista. “The Conventionality Control of Investment Arbitrations: Enhancing Coherence through Dialogue". Transnational Dispute Management Journal (TDM). 2013, vol 1.

5 KAUSHAL, Asha. "Revisiting history: how the past matters for the present backlash against the foreign investment regime". Harvard International Law Journal. 2009, vol 50, n² 2; JACOB, Marc. "International investment agreements and human rights". INEF Research PaperSeries 
quienes en definitiva fijen la extensión concreta de los parámetros de protección de los inversores, con prácticamente nulas posibilidades de revisión. La situación se agrava porque los árbitros se designan para cada caso y no hay un régimen de unificación de criterios, por ejemplo, mediante un sistema permanente de revisión.

En ese contexto, cuando la discrecionalidad que esa indeterminación trae aparejada se combina con una visión del TBI que no toma en cuenta los deberes que el Estado tiene frente a su población (por ejemplo en materia ambiental, salud pública, agua, derechos humanos, igualdad racial, etc.) ocurren interpretaciones expansivas de los derechos de los inversores que prácticamente los ponen a resguardo del riesgo empresario y obturan la posibilidad de evolución institucional y desarrollo del país receptor.

En definitiva, la arquitectura legal en materia de protección de las inversiones extranjeras implica una inevitable transferencia de potestades regulatorias nacionales a favor de quienes resuelven las disputas entre los inversores y los Estados que los alojan. Y esa transferencia se da a partir de acuerdos que en su inmensa mayoría no contienen referencias explícitas a los derechos humanos. Esa carencia, sumada a una visión algo estrecha, ha llevado a numerosos laudos a asumir que el régimen jurídico de protección de las inversiones y el de los derechos humanos son dos campos herméticamente separados que no pueden interactuar de manera alguna.

Como resultado de esa visión, en laudos clave se ha ignorado la relevancia que poseen los derechos humanos al momento de dirimir una controversia entre el Estado receptor y el inversor ${ }^{6}$. Esa omisión ha habilitado una gradual expansión del alcance de las garantías de los inversores por vía de interpretación arbitral, tendencia que puede minar la capacidad de los Estados para poner en práctica diferentes medidas fundadas en el interés público.

\subsection{El régimen de derechos humanos. Promoción del cambio}

En paralelo a su inserción en los sistemas de protección de las inversiones -que son recurrentemente leídos en los términos anteriores-, los países de nuestra región se encuentran sujetos a una serie de

\footnotetext{
Human Rights, 2010, $\mathrm{n}^{\circ} 3$.

6 Por ejemplo, al desestimar el pedido de intervención de comunidades indígenas en litigios relacionados con disputas de tierras en Zimbabwe, paneles arbitrales expresaron que no existían pruebas sobre la existencia de una interdependencia entre el derecho de inversiones y los derechos humanos en función de la cual la falta de consideración del contenido de las normas de derechos humanos convirtiera a la decisión arbitral en jurídicamente incompleta (Border Timbers Limited y otros v. República de Zimbawe -Caso CIADI No ARB/10/25- y Bernhard von Pezold y otros v. República de Zimbawe - Caso CIADI No ARB/10/15-, Orden Procesal No 2, 26 de junio de 2012, párr. 58).
} 
instrumentos universales y regionales de protección de los derechos humanos que también conllevan una transferencia relevante de facultades nacionales hacia estamentos que no dependen directamente de la voluntad estatal e imponen una serie de obligaciones que condicionan crecientemente el margen de actuación de las autoridades locales.

Sobre la base de la universalidad e inviolabilidad de los derechos tutelados, el diseño de las diferentes convenciones internacionales en la materia recepta los siguientes lineamientos: a) la fijación de pisos mínimos de protección de esos derechos que limitan el margen de acción de los Estados; $b$ ) la imposibilidad de los Estados de invocar su ordenamiento jurídico interno, sus tradiciones culturales o cualquier otro elemento de su identidad nacional para justificar el apartamiento de esos pisos mínimos de protección, y; c) el establecimiento de tribunales internacionales con la facultad de controlar la compatibilidad de las prácticas domésticas de cualquier índole con las reglas de los tratados, declarar al Estado incurso en responsabilidad internacional ante un supuesto de violación de esas reglas y condenarlo a hacer cesar la infracción e indemnizar los daños causados.

Esos rasgos responden a que este tipo de acuerdos está orientado, más que a establecer un equilibrio de intereses entre Estados, a garantizar el goce de los derechos y libertades del ser humano. Los Estados que pasan a integrar los mecanismos de las convenciones deciden unirse y limitar su esfera de acción, tanto interna como externa, para asegurar mediante una acción colectiva, que se estima más eficiente que la tradicional, la vigencia tangible de los derechos humanos. De ese modo, los miembros deciden reducir sus potestades propias para ampliar en conjunto su capacidad de protección de esos intereses. La limitación singular del campo de acción estatal por medio de una autorrestricción se traduce en una ampliación correlativa de ese campo por medio de la cooperación.

Para asegurar sus cometidos, las convenciones internacionales de derechos humanos imponen a los gobiernos tres tipos de obligaciones en relación a los derechos que ellas consagran.

La primera de ellas es la obligación de respeto, que demanda de los Estados que se abstengan de interferir directa o indirectamente con el disfrute del derecho de que se trate. Es decir, que no incurran por sí mismos en prácticas que impliquen lesionar el derecho.

En segundo lugar, una obligación de garantía, asociada a la remoción de los obstáculos al ejercicio efectivo de los derechos, esto es, la provisión de los recursos y la facilitación de las actividades necesarias para un acceso igualitario a ese ejercicio.

Por último, la obligación de protección requiere que el Estado prevenga la interferencia de terceros en el disfrute de cada derecho. 
El concepto de terceros incluye a individuos, grupos, empresas, corporaciones y otras entidades, por lo que proteger implica diseñar y poner en práctica medidas regulatorias tendientes a impedir a cualquier sujeto privado la realización de conductas lesivas. El Estado no sólo debe observar por sí mismo las reglas de los pactos, sino que también tiene a cargo asegurar que los particulares hagan lo mismo en sus relaciones privadas ${ }^{7}$.

Estas obligaciones estatales en materia de derechos humanos pueden ser englobadas, desde el punto de vista económico, bajo la idea de espacio fiscal tendiente a facilitar estrategias nacionales efectivas para el desarrollo ${ }^{8}$. El espacio fiscal necesita un cierto espacio político y jurídico.

En especial en aquellos contextos donde el goce de los derechos se encuentra más insatisfecho, el cumplimiento de esas obligaciones por parte del Estado involucra necesariamente la adopción continua y sistemática de una serie de medidas encaminadas a revertir esa falta de acceso a su ejercicio efectivo. Las obligaciones internacionales en este campo poseen, así, un contenido dinámico e incremental que responde tanto a la interpretación evolutiva que es inherente a toda categoría de derechos humanos, como al principio de realización progresiva específico de los económicos, sociales y culturales (DESC).

Ese avance evolutivo en la protección de los derechos humanos puede, en ocasiones, tensionar con la pretensión de estabilidad para los inversores que los TBIs encarnan, pues hace a un aspecto natural del sistema que el cumplimiento de los compromisos estatales -especialmente en aquellos países con menores índices de satisfacción del derecho de que se trate- involucre con frecuencia la modificación del marco jurídico y las prácticas estatales. De eso se trata, precisamente, llevar a la práctica los mandatos contenidos en las convenciones.

Como vemos, en el marco de los tratados de derechos humanos, los Estados tienen la obligación de adecuar sus marcos jurídicos y sus prácticas administrativas, judiciales o de cualquier otro carácter para asegurar el goce efectivo de esos derechos. Esa vocación transformadora conlleva un indudable riesgo regulatorio -esto es, el riesgo de que las agencias estatales modifiquen sus políticas y criterios $^{-}{ }^{9}$, que debe ser

7 Véase ONU. Consejo de Derechos Humanos. Principios Rectores sobre Empresas y Derechos Humanos. Proteger, Respetar y Remediar (A/HRC/RES/17/4, 16 de junio de 2011); BILCHITZ, David. "The Ruggie Framework: an Adequate Rubric for Corporate Human Rights Obligations?". Sur International Journal on Human Rights, 2010, vol 7, n 12; BLITT, Robert C. "Beyond Ruggie’s Guiding Principles on Business and Human Rights: Charting an Embracive Approach to Corporate Human Rights Compliance". University of Tennessee Legal Studies Research Paper. 2011, n 158.

8 Sobre las tensiones entre los acuerdos de inversión y el espacio fiscal de los países ver ampliamente UNCTAD. Trade and Development Report. Ginebra: UNCTAD, 2014.

9 DESIERTO, Diane. "Sovereign Policy Flexibility for Social Protection: Managing Regulatory Risk in IIAs. Mauritius International Arbitration Conference. 2012. 
ponderado por el inversor al momento de evaluar el entorno de su emprendimiento comercial, como un expresión de debida diligencia.

\section{TENSIONES ENTRE EL AVANCE EN LA PROTECCIÓN DE LOS DERECHOS HUMANOS Y LA ESTABILIDAD DEL ENTORNO DE LA INVERSIÓN}

Las inversiones extranjeras suelen involucrar proyectos económicos de gran magnitud, larga duración y capital intensivo, lo cual trae aparejada la posibilidad de que sus condiciones de funcionamiento se modifiquen, generando un impacto negativo sobre el emprendimiento. Cuando esa variación adversa responde a una medida estatal, el empresario puede alegar que el Estado modificó sus legítimas expectativas al momento de hacer la inversión, dando lugar a reclamos indemnizatorios. El núcleo histórico y conceptual de los TBIs consiste en brindar salvaguardas a los inversores frente a los golpes de timón gubernamentales que conducen a una modificación negativa del entorno en el cual se desenvuelve su negocio.

En contrapartida, hemos visto que el avance de las condiciones de protección constituye un rasgo esencial del sistema de derechos humanos que se materializa en la premisa de universalidad y los dispositivos de interpretación evolutiva y progresividad ${ }^{10}$. Como producto de esa vocación incremental, los estándares en materia de derechos humanos se han intensificado de modo sustancial en las últimas décadas, captando gradualmente ámbitos de la acción gubernamental que antes les eran remisos. Por cierto, es razonable esperar que las exigencias frente a las tres generaciones de derechos humanos sigan expandiéndose en las próximas décadas, por lo menos hasta tanto se cumpla el disfrute universal de sus pisos mínimos. En consecuencia, y contrariamente a un relato bastante arraigado, la modificación de los marcos legales y de las prácticas gubernamentales de los países en desarrollo no obedece tan sólo al cambio de vientos políticos o a situaciones de volatilidad, sino también a la necesidad de abandonar la condición jurídica de incumplidores crónicos frente a mandatos internacionales imperativos.

En ese contexto, es natural que los crecientes condicionamientos de los Estados como resultado de sus obligaciones de respeto, garantía y protección involucren la necesidad de adecuar su derecho interno para que resulte consistente con los tratados y de adoptar aquellas medidas regulatorias necesarias para su efectivización. Esa obligación

10 Como se ha expresado, "los derechos humanos son, además de exigibles, progresivos y expansivos, caracteres estos que imponen una actitud interpretativa consecuente y, por ende, la necesidad de considerar en cada caso, no sólo el sentido y alcances de las propias normas interpretadas, en su texto literal, sino también su potencialidad de crecimiento" (Corte IDH, OC-4/84, Propuesta de Modificación a la Constitución Política de Costa Rica Relacionada con la Naturalización, 19 de enero de 1984, voto separado del juez Piza Escalante, párr. 3). 
puede tener un efecto adverso en los intereses de los inversores, que -en consecuencia- exigirán compensaciones bajo los estándares de los TBIs, todo lo cual puede desalentar esa implementación doméstica o la asunción de nuevos compromisos internacionales.

Veamos algunas expresiones concretas de esta tensión entre la progresividad y la búsqueda de estabilidad.

\subsection{La adecuación del derecho interno frente al trato justo y equitativo}

\section{a) El deber de adecuación del derecho interno como obligación primaria del Estado}

Los arts. 1.1 y 2 de la CADH fijan los siguientes deberes esenciales: $i$ ) como consecuencia de las obligaciones generales de respetar y garantizar los derechos fundamentales (art. 1.1), los Estados deben adoptar medidas positivas, evitar tomar iniciativas que limiten o conculquen un derecho fundamental, y suprimir las medidas y prácticas que actualmente los restrinjan o vulneren ${ }^{11}$; ii) como consecuencia de la obligación adicional del art. 2, los Estados deben -cuando el ejercicio de un derecho no se encuentre todavía garantizado- adecuar su ordenamiento jurídico -en el plano normativo o de cualquier otro tipo, es decir, incluyendo leyes, sentencias, reglamentos, actos o hechos- para permitir tal ejercicio.

Todo el sistema se asienta en la consecución de un logro, el goce efectivo de los derechos humanos, y para ello se exige a los Estados conductas que van desde la abstención de violaciones (respeto), la adopción de medidas de contenido positivo (garantía) hasta la adecuación de todo el obrar estatal a los cánones convencionales. Para la Corte "garantizar implica la obligación del Estado de tomar todas las medidas necesarias para remover los obstáculos que puedan existir para que los individuos puedan disfrutar de los derechos que la Convención reconoce"12. Por consiguiente, no sólo es ilícita toda forma de ejercicio del poder público que viole por sí misma los derechos reconocidos por el pacto $^{13}$, sino también la tolerancia del Estado a circunstancias o condiciones que impidan a los individuos acceder a su goce ${ }^{14}$. Cualquiera sea el origen o la forma que asuma, toda medida estatal que se traduzca en la lesión o desamparo de un derecho convencional se encuentra

11 Corte IDH, OC-18/03, Condición Jurídica y Derechos de los Migrantes Indocumentados, 17 de septiembre de 2003, párrs. 81 y 173.

12 Corte IDH, OC-11/90, Excepciones al Agotamiento de los recursos internos (artículo 46.1, 46.2. a y 46.2.b Convención Americana sobre Derechos Humanos), 10 de agosto de 1990, párr. 34.

13 Corte IDH, Velásquez Rodríguez v. Honduras. Fondo. 29 de julio de 1988, párr. 169.

14 Corte IDH, "Cinco Pensionistas" v. Perú. Fondo, Reparaciones y Costas. 28 de febrero de 2003, párr. 163. 
vedada por las directivas generales de los arts. 1 y 2 de ese instrumento ${ }^{15}$. El deber general de adecuación establecido en el art. 2 de la $\mathrm{CADH}$ implica la adopción de medidas en dos vertientes. Por una parte, la supresión de las normas y prácticas de cualquier naturaleza que entrañen violación a las garantías previstas en la convención. Por la otra, la expedición de normas y el desarrollo de prácticas conducentes a la efectiva observancia de dichas garantías ${ }^{16}$. La obligación de la primera vertiente se incumple mientras la norma o práctica violatoria se mantenga en el ordenamiento jurídico ${ }^{17} \mathrm{y}$, por ende, se satisface con su modificación ${ }^{18}$, derogación, anulación ${ }^{19}$, o reforma ${ }^{20}$. En el segundo supuesto, el deber convencional se cumple con el dictado de las regulaciones y la implementación de las prácticas encaminadas hacia la observancia de los derechos, es decir, con medidas positivas.

Es así que cuando la igualdad real para el acceso a los derechos no se encuentra garantizada en un país -y ello trae aparejada su falta de efectividad para ciertos sectores- es deber del gobierno adoptar las medidas tanto legislativas como "de otro carácter" que permitan -a través de la neutralización de los factores determinantes de esa desigualdadhacer efectivos esos derechos.

Por tal razón, si bien a primera vista podría considerarse que el art. 2 de la CADH contiene un compromiso sobreabundante, desde que el deber de respetar y garantizar incluye el de dictar las medidas necesarias para hacer efectivos los derechos, su sentido reside en hacer más determinantes las exigencias internacionales impuestas al Estado, el cual no sólo no puede invocar el contenido su derecho interno para justificar una violación, sino tampoco las carencias del mismo para excusar la falta de efectividad de un derecho convencional.

A este mandato genérico se suma, en el marco de los DESC, el principio de progresividad plasmado en el art. 2 del PIDESC, que obliga

15 Corte IDH, OC-4/84, Propuesta de Modificación a la Constitución Política de Costa Rica Relacionada con la Naturalización, 19 de enero de 1984, párr. 53.

16 Corte IDH, Bulacio v. Argentina. Fondo, Reparaciones y Costas. 18 de septiembre de 2003, párr. 143; OC-13/93, Ciertas Atribuciones de la Comisión Interamericana de Derechos Humanos (artículos 41, 42, 44, 46, 47, 50 y 51 Convención Americana sobre Derechos Humanos), 16 de julio de 1993, párr. 26; La Cantuta v. Perú. Fondo, Reparaciones y Costas. 29 de noviembre de 2006, párr. 172; Ximenes Lopes v. Brasil. Fondo, Reparaciones y Costas. 4 de julio de 2006, párr. 83; Gómez Palomino v. Perú. Fondo, Reparaciones y Costas. 22 de noviembre de 2005, párr. 91; y Raxcacó Reyes v. Guatemala. Fondo, Reparaciones y Costas. 15 de septiembre de 2005. párr. 87.

17 Corte IDH, "La Última Tentación de Cristo" (Olmedo Bustos y otros) v. Chile. Fondo, Reparaciones y Costas. 5 de febrero de 2001, párrs. 87 a 90.

18 Corte IDH, Fermín Ramírez v. Guatemala. Fondo, Reparaciones y Costas. 20 de junio de 2005, párrs. 96 a 98; Hilaire, Constantine, Benjamin y Otros v. Trinidad y Tobago. Fondo, Reparaciones y Costas. 21 de junio de 2002, párr. 113.

19 Corte IDH, Caesar v. Trinidad y Tobago. Fondo, Reparaciones y Costas. 11 de marzo 2005, párrs. 91, 93 y 94.

20 Corte IDH, Almonacid Arellano y Otros v. Chile. Excepciones Preliminares, Fondo, Reparaciones y Costas. 26 de septiembre de 2006, párr. 118; Raxcacó Reyes, cit., párr. 87. 
a los Estados a adoptar medidas que deben funcionar como un camino adecuado para lograr paulatinamente la plena efectividad de esos derechos, habida cuenta de la imposibilidad de garantizarla de modo inmediato.

Al respecto el Comité de DESC de Naciones Unidas ha dicho que el concepto de progresiva efectividad constituye un reconocimiento del hecho de que la plena efectividad de todos los DESC en general no podrá lograrse en un breve período de tiempo. Sin embargo, el hecho de que la efectividad a lo largo del tiempo, o en otras palabras progresivamente, se prevea en relación con el Pacto no se ha de interpretar equivocadamente como privando a la obligación de todo contenido significativo. Por una parte, se requiere un dispositivo de flexibilidad necesaria que refleje las realidades del mundo real y las dificultades que implica para cada país asegurar la plena efectividad de los derechos económicos, sociales y culturales. Por otra parte, la frase debe interpretarse a la luz del objetivo general del PIDESC, que es establecer claras obligaciones para los Estados parte con respecto a la plena realidad de los derechos de que se trata. Impone así una obligación de proceder lo más expedita y eficazmente posible con miras a lograr ese objetivo. Además, todas las medidas de carácter deliberadamente retroactivo en este aspecto que configuren un supuesto de regresividad requerirán la consideración más cuidadosa y deberán justificarse plenamente por referencia a la totalidad de los derechos previstos en el Pacto y en el contexto del aprovechamiento pleno del máximo de los recursos de que se disponga ${ }^{21}$.

Como vemos, tanto las obligaciones genéricas de la $\mathrm{CADH}$ como la específica del PIDESC imponen al Estado la revisión de su marco jurídico y económico, la reformulación de sus prácticas administrativas, regulatorias o judiciales y -en suma- la reestructuración del funcionamiento estatal de un modo que le permita alcanzar plenamente las metas convencionales. La transformación es un aspecto constitutivo del régimen de derechos humanos.

\section{b) La expansión del principio de trato justo y equitativo frente a los cambios regulatorios}

La contracara de la tendencia transformadora afincada en las bases del sistema de derechos humanos puede encontrarse en una corriente interpretativa expansiva del principio de trato justo y equitativo (TJE) contenido en los BITs que cuenta con bastante predicamento.

21 CESCR. Observación General № 3, La índole de las obligaciones de los Estados parte (párr. 1 del artículo 2 del Pacto), 1990, párr. 9. Sobre las complejidades de este punto, véase SKOGLY, Sigrun. "The Requirement of Using the 'Maximum of Available Resources' for Human Rights Realisation: A Question of Quality as Well as Quantity?”. Human Rights Law Review. 2012, vol $12, \mathrm{n}^{\circ} 3$. 
En términos históricos, el TJE fue originalmente concebido como una expresión del estándar consuetudinario de trato mínimo a los extranjeros, que cuenta con un fuerte arraigo en el derecho internacional y que demanda de los Estados conceder a los nacionales de otros países garantías mínimas contra la denegación de justicia, la arbitrariedad y la discriminación. El dato relevante, a los efectos de este análisis, es que ese estándar consuetudinario expresa un umbral elevado para considerar a la conducta gubernamental como ilícita, por lo que su violación sólo comprende las conductas más graves y ultrajantes; de ahí su condición de mínimo.

Lo cierto es que la aplicación del TJE ha ido alejándose paulatinamente de esos mínimos internacionales para incluir aspectos de governanza, como la transparencia, previsibilidad o la coherencia. Esa ampliación del concepto ha llevado a que un cúmulo de conductas gubernamentales que no se consideraban equiparables a violación del estándar mínimo consuetudinario sean concebidas ahora como violatorias de este principio de los TBIs, ampliando de ese modo las salvaguardas a favor de los inversores pero reduciendo también el margen de maniobra de los Estados.

La razón de esa ampliación reside en la interpretación arbitral. Si bien algunos paneles han mantenido una interpretación consistente con el origen histórico de la figura -requiriendo consecuentemente un nivel alto de gravedad del comportamiento gubernamental para que se configure una violación al TJE- muchos otros comenzaron a interpretarlo como un principio diferente de ese estándar consuetudinario, considerándolo como autónomo y dotado de contenido propio. De esa manera, en lugar de derivar el contenido de la norma de su fuente original (el derecho internacional consuetudinario), estos tribunales optaron centrarse en el significado literal de las diferentes disposiciones de los TBIs que consagran esta garantía ${ }^{22}$. Al hacerlo, empezaron a encontrar en el TJE mucho más que las garantías internacionales tradicionales, pasando a un bajo umbral de ilicitud en el comportamiento ${ }^{23}$.

Como producto de ese viraje, el TJE se erigió como una de las normas de mayor alcance de protección de la inversión, y su utilización

22 UNCTAD. Fair and Equitable Treatment. Ginebra: Naciones Unidas, 2012.

23 Saluka v. República Checa (2006, CNUDMI), párr. 293; Merrill \& Ring v. Canadá (2010, UNCITRAL -NAFTA-), párr. 210. El estándar consuetudinario fue precisado en el caso Neer (Mexico-United States General Claims Commission, LFH Neer and Pauline Neer -United States v. Mexico-, 1926), en el cual se requirió que la conducta sea "atroz" o "indignante". Por cierto, aún cuando desde la época del caso Neer lo que se concibe como una conducta atroz puede haber variado, lo cierto es que la vinculación al mínimo internacional implica dejar en claro que sólo los actos muy graves pueden ser vistos como una violación de los TBIs, es decir, que se aplica con criterio restrictivo. Véase Waste Management v. México (2004, Caso CIADI N ARB-AF/00/3), párr. 98; Glamis Gold Ltd v. Estados Unidos (2009, UNCITRAL NAFTA-), párr. 600; GAMI Investments Inc. v. México (2004, UNCITRAL -NAFTA-), párr. 97; International Thunderbird Gaming Corporation v. México (2006, UNCITRAL -NAFTA-), párr. 194. 
aumentó de manera exponencial. La flexibilidad y vaguedad de su contenido normativo, que es continuamente redefinido de acuerdo a las circunstancias de cada caso y del tratado pertinente, hicieron del TJE un estándar que todo lo abarca y que se encuentra en permanente expansión, y la forma preferida por los paneles arbitrales para justificar una condena al Estado ${ }^{24}$.

En el caso Metalclad del año 2000 se produjo la primera muestra del abandono del estándar mínimo internacional y su reemplazo por criterios de buena governanza, al considerarse configurada una violación al TJE con base en la ausencia de transparencia por parte del Estado. El tribunal interpretó que ese estándar imponía en cabeza de las autoridades el deber de corregir cualquier malentendido o confusión frente al inversor, a fin de asegurar la estabilidad del contexto de la inversión, e implicaba también que no debía "haber lugar a duda o incertidumbre" frente a "todo requerimiento legal pertinente a efecto de iniciar, completar u operar exitosamente inversiones realizadas, o que se tenga intención de realizar" 25 . Con esa base, y alejándose claramente del mínimo estándar internacional, se entendió violado el FET por cuando el Estado "no cumplió con asegurar un marco transparente y previsible para la planeación del negocio e inversión"26.

Esta reformulación del concepto fue objeto de diferentes críticas, e incluso condujo a la emisión de una nota interpretativa del Tratado de Libre Comercio de América del Norte (NAFTA) orientada explícitamente a atar el contenido del TJE al mínimo internacional ${ }^{27}$. A medida que los argumentos encaminados a desligar al TJE del estándar mínimo internacional se iban haciendo menos sustentables en función de las críticas y las claras señales de los Estados que las interpretaciones jurisdiccionales no eran un reflejo de las intenciones de los Estados, la doctrina doméstica de las expectativas legítimas se abrió camino en el arbitraje de inversión para expandir nuevamente los límites de este principio.

En efecto, el segundo viraje quellevó a un boom en la utilización del TJE consistió en poner como centro del principio a las expectativas del

24 DAVITTI, Daria. "On the Meanings of International Investment Law and International Human Rights Law: The Alternative Narrative of Due Diligence". Human Rights Law Review. 2012, vol 12, nº 3 .

25 Metalclad Corporation v. México (2000, Caso CIADI No ARB AF/97/1), párr. 76.

26 Metalclad, cit, párr. 99.

27 Luego del laudo Metalclad, la Comisión de Libre Comercio del NAFTA emitió la siguiente nota interpretativa al art. artículo 1105(1) del tratado: "1. El artículo 1105(1) establece el nivel mínimo de trato a los extranjeros propio del derecho internacional consuetudinario, como el nivel mínimo de trato que debe otorgarse a las inversiones de los inversionistas de otra Parte. 2. Los conceptos de "trato justo y equitativo" y "protección y seguridades plenas" no requieren un trato adicional al requerido por el nivel mínimo de trato a los extranjeros propio del derecho internacional consuetudinario, o que vaya más allá de éste" (Comisión de Libre Comercio del TLCAN, "Notas interpretativas de ciertas disposiciones del Capítulo 11", 31 de julio de 2001). 
inversor. Por ejemplo, en Tecmed ${ }^{28}$, se interpretó que el TJE "exige de las Partes Contratantes del Acuerdo brindar un tratamiento a la inversión extranjera que no desvirtúe las expectativas básicas en razón de las cuales el inversor extranjero decidió realizar su inversión. Como parte de tales expectativas, aquél cuenta con que el Estado receptor de la inversión se conducirá de manera coherente, desprovista de ambigüedades y transparente en sus relaciones con el inversor extranjero, de manera que éste pueda conocer de manera anticipada, para planificar sus actividades y ajustar su conducta, no sólo las normas o reglamentaciones que regirán tales actividades, sino también las políticas perseguidas por tal normativa $y$ las prácticas o directivas administrativas que les son relevantes"29.

Inclusive, en $M D T v$. Chile se hace referencia a un deber activo de protección del inversor y no sólo de abstención de conductas arbitrarias o perjudiciales respecto de aquel. Al parecer, la neutralidad hacia el inversor de parte del Estado no es suficiente, sino que también hay que velar por sus intereses ${ }^{30}$.

Como resultado de ese cambio de rumbo, el TJE ratificó su protagonismo como fórmula omnicomprensiva que permite conjugar los efectos legales de todos los estándares de los TBIs y que puede ser invocada eficazmente en lugar de la expropiación, no arbitrariedad, discriminación, e incluso de las cláusulas paraguas ${ }^{31}$. Esa ampliación

28 Técnicas Medioambientales Tecmed v. México (2003, Caso CIADI No ARB-AF/00/2, párr. 154); MTD v. Chile (2004, Caso CIADI No ARB/01/7, párrs. 114 y 115). El Comité de Anulación en este último caso observó que la ponderación de las expectativas del inversor como fuente de obligaciones para el Estado resulta cuestionable, pues esas obligaciones derivan del TBI aplicable y no de cualquier aspiración que el inversor pueda aducir (2007, Caso CIADI No ARB/01/7, Decisión sobre Anulación, párr. 67). Dando cuenta de los gruesos desacuerdos que atraviesan la jurisprudencia arbitral, en el caso Walter Bau v. Tailandia (2009, CNUDMI, párr. 11.7) se consideró a ese cuestionamiento como "circular e inaceptable".

29 Tecmed, cit., párr. 154. Como se ha destacado con lucidez, "el "estándar" de Tecmed en realidad no constituye estándar alguno; es, por el contrario, la descripción de la regulación pública perfecta en un mundo perfecto, a la cual todos los Estados deberían aspirar pero que muy pocos (si alguno) llegará alguna vez" (Douglas, Zachary, "Nothing if Not Critical for Investment Treaty Arbitration: Occidental, Eureko and Methanex", Arbitration International, Vol. 22, 2006, p. 28). Véase Middle East Cement Shipping and Handling Co. S.A. v. Egipto (2002, Caso CIADI No ARB/99/6); Biwater Gauffv. Tanzania (2008, Caso CIADI No ARB/05/22). En $C M S$ se sostuvo que "no puede caber duda alguna de que la estabilidad del entorno jurídico y empresarial es un elemento esencial del trato justo y equitativo" (CMS Gas Transmission Company v. Argentina, 2005, Caso CIADI No ARB/01/8, párr. 274), también LG\&E Energy Corp. v. Argentina (2006, Caso CIADI No ARB/02/1, párr. 127 y ss.) y Duke Energy v. Ecuador (2008, Caso CIADI No ARB/04/19, párr. 340). Con una posición menos protectoria del inversor ver Parkerings-Compagniet AS v. Lituania (2007, Caso CIADI No ARB/05/8, párr. 333). La jurisprudencia también recalca que la violación del trato justo y equitativo no presupone mala fe de parte del Estado, con lo cual aún cuando la autoridad pública haya actuado persiguiendo un fin legítimo sin abuso, discriminación o arbitrariedad, puede lesionarse esta garantía. Ver CMS, cit., párr. 280; Azurix v. Argentina (2006, Caso CIADI No ARB/01/12, párr. 372); Mondev v. Estados Unidos (2002, Caso CIADI No ARB-AF/99/2, párr. 116); Waste Management v. México (2004, Caso CIADI N ARB-AF/00/3, párr. 97).

30 Una lectura menos deferente hacia el inversor se advierte en Marvin Feldman v. México (2002, Caso CIADI No ARB-AF/99/1) o en Waste Management, cit.

31 SGS Société Générale de Surveillance SA v. Filipinas, cit. párr. 162; 8 ICSID Rep 518 (2005); 
terminó por forzar los límites de la responsabilidad internacional de los Estados ante los actores empresariales privados, en especial porque la idea de conductas ilícitas internacionales pasó de pautas de cierta gravedad a una laxa idea de buen gobierno ${ }^{32}$. Las nociones de transparencia, consistencia y estabilidad regulatoria se transformaron en componentes esenciales del TJE y fueron utilizados recurrentemente por los paneles arbitrales ${ }^{33}$, aumentando de modo significativo la posibilidad de condena en función de este principio.

\section{c) Una lectura moderada del trato justo y equitativo. La debida diligencia del inversor}

Por cierto, esa expansión del concepto resulta problemática para el desempeño del Estado. Si el TJE incluye el derecho del inversor de conocer de antemano no sólo las normas o reglamentaciones, sino también las políticas y las prácticas o directivas administrativas que les son relevantes ${ }^{34}$, las obligaciones y limitaciones impuestas en el país receptor son de largo alcance y pueden generar incertidumbre en las autoridades, derivando en un enfriamiento regulatorio. Este fenómeno se produce cuando las condenan previenen a las autoridades domésticas de introducir aquellas nuevas normas y prácticas administrativas destinadas a mejorar la regulación, lo cual debilita las posibilidades de intervención estatal orientada a alcanzar aquellas metas económicas, sociales y ambientales que vienen exigidas desde otras ramas del derecho internacional ${ }^{35}$.

El sobredimensionamiento de las legítimas expectativas del inversor -que lleva a ver en cualquier cambio del entorno legal y de negocios adverso a sus intereses una violación del TJE- ignora el hecho de que los inversores deberían legítimamente esperan cambios en las leyes y reglamentaciones, como un aspecto obvio del normal funcionamiento de los procesos jurídicos y políticos de la economía en la que operan.

Para lograr un punto de equilibrio es necesario evitar la identificación de este estándar con un derecho del inversor a la inalterabilidad de todas las regulaciones y políticas públicas que gobiernan su emprendimiento. Sólo cuando estamos frente a cláusulas de estabilización corresponde reconocer un derecho a la permanencia de una regulación, pero aún aquellas resultan inoponibles frente al

\footnotetext{
Noble Ventures Inc v. Rumania (2005, Caso CIADI No ARB/01/11), párr. 182.

32 Véase SATTOROVA, Mavluda. "Investment Treaty Breach as Internationally Proscribed Conduct: Shifting Scope, Evolving Objectives, Recalibrated Remedies?". Trade Law \& Development. 2012, vol 4, n' 2 .

33 Occidental v. Ecuador (2004, LCIA Caso o UN 3467), párr. 183; Enron v. Argentina (2007, Caso CIADI No ARB/01/3), párr. 260; PSEG Global y otros v. Turquía (2007, Caso CIADI No ARB/02/5), párr. 253.

34 Biwater Gauff v. Tanzania (2008, Caso CIADI No ARB/05/22, párr. 602.

35 UNCTAD. Fair and Equitable Treatment, Op. cit.
} 
deber de protección, al constituir los derechos humanos una necesaria excepción a esos compromisos. Una auditoría básica de las obligaciones internacionales en materia de derechos humanos a cargo del Estado en el que se planea invertir bastaría para que el inversor pueda albergar expectativas realistas y legítimas acerca de lo que ese Estado puede hacer en el futuro.

Por otra parte, corresponde inferir de este principio sustancial el deber del Estado de abstenerse de acciones irrazonables, mas no de preservar y promover activamente los intereses del empresario extranjero. No resulta consistente, entonces, demandar una suerte de "paternalismo" sobre el inversor, cual si éste fuera incapaz de evaluar sus decisiones con una diligencia mínima ${ }^{36}$. Antes bien, ese trato justo y equitativo debe ser interpretado en consonancia con el cumplimiento por parte del inversor de los deberes de debida diligencia, respeto de la ley, eficiencia, responsabilidad y transparencia en su evaluación y ejecución ${ }^{37}$.

En El Paso ${ }^{38}$ se adopta, a nuestro juicio, la línea correcta que permite poner en su justo lugar a la garantía del TJE de un modo que no incapacite a los Estados para perseguir las metas que los tratados de derechos humanos le imponen.

Se dijo allí que "si se admitiera la fórmula frecuentemente reiterada que postula que "la estabilidad del marco jurídico y de negocios es un elemento esencial del trato justo y equitativo", las leyes jamás podrían modificarse: este simple enunciado demuestra su irrelevancia. Este estándar de conducta, aplicado estrictamente, no resulta realista, ni tampoco es el objeto de los TBI que los Estados garanticen que las condiciones jurídicas y económicas en las que se realiza una inversión se mantendrán inalterables ad infinitum"39.

Enfatizó que, en tanto "La evolución es un elemento intrínseco de la vida económica y jurídica" ", las expectativas legítimas "no pueden limitarse a las expectativas legítimas del inversor, sino que deben corresponderse con las expectativas objetivas que se pueden deducir de las circunstancias con la debida consideración de los derechos del Estado" ${ }^{41}$. En otras palabras, "el estándar de trato justo y equitativo no puede suponer la inmutabilidad del orden jurídico, el mundo económico

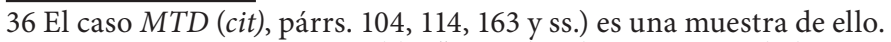

37 BOHOSLAVSKY, Juan Pablo. "Tratados de protección de las inversiones e implicaciones para la formulación de políticas públicas (especial referencia a los servicios de agua potable y saneamiento)". s.l: CEPAL, 2010.

38 El Paso Energy International Company v. República Argentina (2011, Caso CIADI No $\mathrm{ARB} / 03 / 15)$.

39 El Paso, cit., párr. 350. Ver también Suez, Sociedad General de Aguas de Barcelona, S.A. y Vivendi Universal, S.A. v. Argentina (2010, Caso CIADI No ARB/03/19). Opinión Separada del Arbitro Pedro Nikken, párr. 20 y ss.

40 El Paso, Op.Cit. párr. 352.

41 El Paso, Op. cit. párr. 358. 
y el universo social, y jugar el papel de una cláusula de estabilización específicamente diseñada en beneficio de los inversores extranjeros con los que el Estado ha firmado acuerdos de inversión"42.

Frente a esa realidad, el inversor debe asumir que la protección de los derechos humanos incrementa el riesgo regulatorio y ejercer la debida diligencia en función de ese dato, pero no puede pretender que el Estado no avance en este campo. Una forma de ponderar el comportamiento del inversor para dilucidar si fue diligente en evaluar el riesgo regulatorio es, precisamente, ver si analizó el nivel de cumplimiento estatal en materia de derechos humanos ${ }^{43}$, pues si el Estado receptor se encuentra lejos de ciertas metas en ese campo, no sólo es razonable sino también deseable esperar que se vayan produciendo medidas encaminadas a su logro.

De manera que la evaluación del riesgo regulatorio constituye una responsabilidad compartida entre el Estado y el inversor. Sin embargo, los tribunales no siempre lo han visto así y han preferido focalizarse en el comportamiento estatal, incluso a partir de una suerte de presunción en contra del Estado cuando se verifica un perjuicio para el inversor. Se ha sostenido que, en caso de duda, el riesgo de ambigüedad de una garantía gubernamental cae más sobre el gobierno que sobre el inversor y el Estado está sujeto a un alto nivel de transparencia y responsabilidad por la claridad y la coherencia en su interacción con los inversionistas extranjeros ${ }^{44}$. De ese modo, en general el test para determinar la razonabilidad de un cambio regulatorio parece centrarse exclusivamente en el Estado receptor, sin tomar en consideración si un inversor diligente debía o no prever y afrontar ese riesgo ${ }^{45}$.

Lo cierto es que, si las expectativas legítimas de los inversores se aceptan para dar contenido al TJE, es necesario que los paneles indaguen en cómo el empresario ha evaluado los riesgos regulatorios al momento de hacer la inversión. Así como "nadie puede tener la expectativa legítima de que no se modifique el marco legal ante una crisis económica de extrema gravedad"46, tampoco nadie que haya relevado mínimamente el grado de cumplimiento de los derechos humanos en un Estado puede esperar que no se modifique el comportamiento estatal para subsanar una eventual inobservancia.

42 El Paso, Op. Cit. párr. 366, con cita de C.P.J.I., Oscar Chinn (Reino Unido c. Bélgica), 1934, Rep., Serie A/B, No. 63, p. 88.

43 Véase Report of the Special Representative of the Secretary-General on the issue of human rights and transnational corporations and other business enterprises, John Ruggie, Addendum, "Principles for responsible contracts: integrating the management of human rights risks into State-investor contract negotiations, guidance for negotiators" (HRC/17/31/Add.3, 2011), Principios $1^{\circ}, 3^{\circ}$ y $4^{\circ}$.

44 International Thunderbird, cit. Opinión Separada del árbitro Thomas W. Wälde, párrs. 4 y 5 .

45 AES Summit Generation Limited y AES-Tisza Erömü Kft v. Hungría (2010, Caso CIADI No ARB/07/22), párrs. 10.3.7 a 10.3.9.

46 El Paso, Op. cit. párr. 374. 


\subsection{Cláusulas de estabilización y derechos humanos}

Si bien se acepta cada vez con mayor frecuencia que, en ausencia de compromisos específicos, el Estado retiene la facultad de modificar su marco legal ${ }^{47}$, la inclusión de cláusulas de estabilización, como expresión de esos compromisos específicos genera diversos interrogantes sobre su compatibilidad con las obligaciones en materia de derechos humanos ¿Puede invocarse una cláusula de estabilización para resistir un cambio legal fundado en el cumplimiento de una obligación internacional en materia de derechos humanos?

Las cláusulas de estabilización se orientan principalmente a contrarrestar cambios de orden tributario, regulatorio, tarifario o societario, así como otras formas de intervención más intensas, como nacionalizaciones o expropiaciones. A esos fines, incluyen diferentes tipos de compromisos ${ }^{48}$ :

a) Cláusulas de intangibilidad, que sujetan al consentimiento del inversor cualquier variación y prohíben al Estado nacionalizar la inversión;

b) Cláusulas de "congelamiento", por las cuales la legislación doméstica aplicable es "congelada" al momento de la conclusión del acuerdo y sus reformas ulteriores se consideran inoponibles al inversor, aislándolo de los cambios regulatorios. En ese caso, el acuerdo adquiere jerarquía preeminente por sobre medidas posteriores de carácter legislativo o administrativo;

c) Cláusulas de consistencia, de acuerdo a las cuales la legislación estatal sólo resulta aplicable si resulta consistente con el acuerdo de inversión, y;

47 Como se ha resuelto en un reciente laudo, ante la ausencia de una cláusula de estabilización o compromiso similar, los cambios en el marco regulatorio solo pueden ser considerados como infracción al trato justo y equitativo en caso de alteraciones drásticas o discriminatorias en las condiciones esenciales de la operación (Toto Costruzioni Generali S.p.A. v. Republica del Líbano, 2012, Caso CIADI No ARB/07/12, párr. 244).

48 COTULA, Lorenzo. Foreign investment contracts, ciudad: International Institute for Environment and Development, 2007, Briefing 4. El Relator Especial de Naciones Unidas sobre derechos humanos y empresas ha destacado que "Con frecuencia los inversores mejoran la protección prevista en los tratados bilaterales de inversión con disposiciones de "estabilización" en contratos confidenciales firmados con los gobiernos de acogida, denominados "acuerdos con el gobierno de acogida" (...) la mayoría de los acuerdos firmados por gobiernos de acogida con países no pertenecientes a la OCDE contienen disposiciones encaminadas a eximir a los inversores del cumplimiento de las nuevas leyes ambientales y sociales, o prevén compensaciones por dicho cumplimiento. Las disposiciones de estabilización más amplias se encuentran en los acuerdos firmados en el África subsahariana, donde 7 de los 11 acuerdos con gobiernos de acogida prevén exenciones de todas las nuevas leyes durante el período de aplicación del proyecto, o indemnizaciones por la observancia de esas leyes, independientemente de su pertinencia para la protección de los derechos humanos o cualquier otro interés público". (ONU, Informe del Representante Especial del Secretario General sobre la cuestión de los derechos humanos y las empresas transnacionales y otras empresas comerciales, "La empresa y los derechos humanos: la puesta en práctica del marco "proteger, respetar y remediar"”-A/HRC/11/13, 22 de abril de 2009-, párr. 32). 
d) Cláusulas de equilibrio económico, que desencadenan la necesidad de renegociar el contrato cuando se producen alteraciones, de modo de restaurar su equilibrio inicial o bien de compensar al inversor. En este caso, y a diferencia de las cláusulas de congelamiento, no se encuentra vedada la modificación regulatoria, pero se establece una disuasión económica para desincentivar ese cambio, consistente en el costo de recomponer la posición económica del inversor.

Tradicionalmente, los paneles arbitrales han admitido la validez de este tipo de compromisos ${ }^{49}$. Sin embargo, también se han precisado las condiciones para su operatividad. En Continental se abordó la cuestión de qué se puede considerar un compromiso especial que dé lugar a "expectativas legítimas razonables" para un inversor extranjero. Se reafirmó allí el requisito de "especificidad del compromiso" que puede dar lugar a expectativas jurídicas razonables, y a tal fin trazó una distinción entre ${ }^{50}$ : i) Declaraciones políticas que - "lamentable pero notoriamente", según el tribunal- no crean ninguna expectativa; ii) enunciados legislativos generales que "generan escasas expectativas", $\mathrm{y}$; iii) compromisos contractuales asumidos por gobiernos que pueden generar expectativas más legítimas y "merecen un examen más detenido" ya que "habitualmente generan derechos y, por lo tanto, expectativas de cumplimiento".

En El Paso se precisó que "un compromiso se puede considerar específico si su objeto preciso fue el de otorgar una garantía efectiva de estabilidad al inversor. Por lo general, los textos generales no pueden contener compromisos de este tipo, ya que no existen garantías de que no se modifiquen con el tiempo"s1.

Ahora bien, aún cuando el compromiso cumpla los recaudos de especificidad, a nuestro juicio el cumplimiento de las obligaciones en materia de derechos humanos constituye un límite claro a la celebración y aplicación de cláusulas de estabilización. En tanto los tratados de derechos humanos disciplinan integralmente todos los ámbitos de la actividad estatal, estén éstos vinculados al plano interno o a la firma y ejecución de otros acuerdos, un Estado parte no puede celebrar válidamente un convenio que lo incapacite para cumplir con sus deberes establecidos en los tratados sin incurrir en responsabilidad internacional por su inobservancia ${ }^{52}$. En consecuencia, pactar la abdicación o

49 AGIP Company v. People's Republic of the Congo, 30 de noviembre de 1979, 21 ILM 726; Government of Kuwait v. American Independent Oil Co. (Aminoil), 24 de marzo de 1982, 21 ILM 976; Revere Copper \& Brass, Inc. v. Overseas Private Investment Corporation (OPIC), Tribunal Arbitral, 24 de agosto de 1978, 56 ILR 257; Texaco Overseas Petroleum Company and California Asiatic Oil Company v. The Government of the Libyan Arab Republic, 19 de enero de 1977, 53 ILR 389.

50 Continental Casualty Property v. República Argentina (2008, Caso CIADI No ARB/03/9) párr. 261.

51 El Paso, Op. cit. párr. 376.

52 CommHR, Decisión No 235/56, 10 de junio 1958; M. \& Co., 9 de febrero de 1990. 
abstención del ejercicio de sus potestades en miras de cumplir con sus compromisos resultaría incongruente con el sometimiento al pacto de derechos humanos.

En función de lo dicho, es posible que con fines de promoción el Estado se comprometa explícitamente bajo cláusulas de estabilización de rango específico y naturaleza contractual ${ }^{53}$; sin embargo, el deber de protección de los derechos humanos constituye la necesaria excepción a ese compromiso ${ }^{54}$.

\subsection{Adecuación de las prácticas domésticas y expropiación indirecta}

Los TBIs suelen prohibir la expropiación -directa o indirecta- ${ }^{-55} \mathrm{si}$ ella no está justificada en el interés público, es discriminatoria o arbitraria y no está seguida de una compensación. Sin embargo, el alcance concreto de esa salvaguarda, en especial respecto de la expropiación indirecta, es altamente discutible y queda librado a la exégesis arbitral, lo cual poco favor le hace a la legitimidad del sistema de TBIs ${ }^{56}$.

Un aspecto del abordaje del estándar de expropiación en los TBIs que resulta muy gravitante para su interacción con los tratados de derechos humanos se vincula con el grado de relevancia que se asigna a los fines estatales al momento de discernir la configuración de una expropiación indirecta.

En este punto, la doctrina del "único efecto" (sole effect) constituye el abordaje ortodoxo que analiza la configuración de una expropiación indirecta centrándose exclusivamente en el efecto de la medida gubernamental sobre la propiedad del inversor, sin computar otros factores como el propósito de la medida o el contexto en el cual ella se adopta. Para que se configure la expropiación debe existir una privación sustancial del valor económico o del uso de la inversión, ese es el factor

\footnotetext{
53 Sobre los "Acuerdos de Estabilidad Legal" desarrollados en Perú, ver Duke Energy Int'l Peru Investments No. 1, Ltd. v. República del Perú (2006, Caso CIADI No ARB/03/28, Decisión sobre Jurisdicción) párr. 31.

54 LEADER, Sheldon. "Human Rights, Risks, and New Strategies for Global Investment". Journal of International Economic Law. 2006, vol 9, nº 3 .

$55 \mathrm{La}$ expropiación puede tomar diferentes formas: se considera "directa” cuando la inversión es nacionalizada o de otra manera directamente sustraída del patrimonio del inversor mediante la transferencia formal del título o la incautación física de los activos y es llamada "indirecta" o "regulatoria" cuando no se altera el título legal de propiedad pero se produce una la interferencia estatal significativa en el uso de dicha propiedad o el disfrute de sus beneficios. OCDE. "Indirect Expropriation" and the "Right to Regulate". In: International Investment Law". OECD Working Papers on International Investment. 2004/04, p. 3.

56 Según ha distinguido cierta jurisprudencia, la expropiación directa ocurriría con la toma del control de la inversión y la consiguiente transferencia de su dominio en favor del Estado receptor, mientras que la indirecta podría derivar de "una interferencia disimulada o incidental del uso de la propiedad que tenga el efecto de privar, totalmente o en parte significativa, al propietario del uso o del beneficio económico que razonablemente se esperaría de la propiedad, aunque no necesariamente en beneficio obvio del Estado receptor" (Metalclad, cit.,).
} 
decisivo, con lo cual los fines gubernamentales quedan desplazados del análisis ${ }^{57}$.

Esa línea resulta inadecuada. Al igual que con las expectativas en el marco del TJE, no corresponde aquí computar sólo las consecuencias sobre el inversor, pues ello implica inmunidad y no igualdad. Es imprescindible discernir el alcance y propósito de la medida. No cualquier alteración del patrimonio del inversor debe ser calificada como expropiatoria, sino sólo aquellas que equivalen a la imposición de un sacrificio especial sobre el empresario.

En efecto, las medidas estatales de alcance general rara vez justifican compensaciones económicas. Ese aspecto constituye una derivación natural de la naturaleza abierta y dinámica de la democracia, que trae aparejada la improponibilidad de una regla indemnizatoria ante los cambios legislativos que afectan a la generalidad de los ciudadanos ${ }^{58}$. Esta noción se expresa en la idea de carga pública y hace que sólo se admita indemnización cuando la igualdad en su distribución se altera. La reparación tiene justamente ese sentido de recomposición del trato igualitario ante los deberes comunitarios.

En un sistema democrático la obediencia a las decisiones colectivas no configura, necesariamente, un daño indemnizable, pues la existencia misma de la organización estatal depende de un deber jurídico en cabeza de cada ciudadano de soportar el costo generado por sus decisiones ${ }^{59}$. Sólo cuando la medida altera el estándar de igualdad ese deber puede dar lugar a indemnización, en la medida en que la ausencia de reparación pueda implicar la imposición de un sacrificio diferencial y/o discriminatorio. Más allá de ese supuesto excepcional, hace a la existencia misma de un sistema de gobierno que no exista una inmunidad contra sus regulaciones por parte de los destinatarios ${ }^{60}$.

Obviamente, la facultad de no obedecer el derecho sancionado

\footnotetext{
57 Por ejemplo, en el laudo Biloune v. Ghana el tribunal sostuvo que no necesitaba establecer las motivaciones del Estado para resolver el caso (Biloune and Marine Drive Complex Ltd v. Ghana Investment Centre and the Government of Ghana, 1989, 95 ILR, párrs. 184-185). En Tippetts se explicitó que el factor central es la presencia de una interferencia del Estado en el uso de la inversión o en el disfrute de sus beneficios y que la intención del gobierno es menos relevante que el efecto de las medidas sobre el propietario (Tippetts $v$. TAMS-AFFA Consulting Engineers of Iran, 6 Cl. Trib. 219, 1984). En Compañía del Desarrollo de Santa Elena S.A. v. Costa Rica (2000, Caso CIADI No ARB/96/1) se sostuvo que el análisis debe centrarse impacto de las medidas sobre el inversor y no tanto en la intención del gobierno o la modalidad adoptada para su implementación, considerando que la finalidad de protección ambiental perseguida por el gobierno carecía de incidencia en el modo de resolver el caso.

58 GARCÍA DE ENTERRÍA, Eduardo. "El principio de confianza legítima como supuesto título justificativo de la responsabilidad patrimonial del Estado legislador". Revista de Administración Pública. 2002, no 159.

59 CSJN Argentina, Columbia, 1992, Fallos, 315:1026; Rebesco, 1995, Fallos, 318:385; Friar, 2006, Fallos, 329:3966.

60 CSJN Argentina, Revestek, 1995, Fallos, 318:1531. En igual tónica, Marvin Feldman, cit., párr. 112; Thunderbird, cit., párr. 208; Saluka, cit., párr. 262; Methanex v. Estados Unidos (2005, NAFTA, p. IV, ch. d, párr. 7).
} 
por la autoridad democrática está lejos de configurar una situación jurídicamente protegida ${ }^{61}$ y por lo tanto la falta de indemnización de una medida regulatoria razonable y proporcional -condición de su exigibilidad- sólo puede implicar una violación al derecho de propiedad si ella constituye una determinación discriminatoria, por imponer exclusivamente al inversor los costos de una decisión que redunda en beneficio de la comunidad (sacrificio especial) ${ }^{62}$. Si ese trato desigual no se configura, por cuanto los costos de la medida recaen sobre el conjunto de agentes económicos del país, la interferencia no sería indemnizable, en tanto aparecería como una simple expresión del ejercicio de las

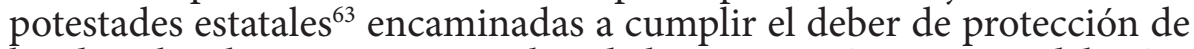
los derechos humanos. De resultas de lo anterior, únicamente deberían calificarse como expropiación -directa o indirecta- las medidas estatales que generen en el inversor un sacrificio especial, entendiendo por tal a la afectación particularizada en una situación jurídicamente protegida.

En conclusión, debemos buscar interpretaciones de los TBIs que no incapaciten al Estado para cumplir su deber de protección en el marco de un sistema democrático. Lo que permite conciliar ese deber con la tutela de los inversores es reconocer a la interdicción de tratos discriminatorios como pauta hermenéutica central de las garantías de los $\mathrm{TBIs}^{64}$.

Al respecto se ha definido a una medida irrazonable o discriminatoria como aquella que -alternativamente-: $i$ ) causa daños al inversor sin servir a ningún propósito legítimo aparente; ii) no se encuentra basada en reglas legales, sino en arbitrariedad, prejuicios o preferencias personales; iii) es dictada por motivos diferentes a los

61 Esa situación jurídicamente protegida no depende de las expectativas del inversor ni de declaraciones implícitas del gobierno (vs. Azurix, cit., párr. 318). Tiene que ser el resultado de la adquisición de un derecho en los términos que fija el ordenamiento del Estado parte.

62 Continental Casualty, cit., párr. 276.

63 Una referencia útil para esa ponderación puede ser el test previsto en el Anexo B.4 del TBI modelo de Estados Unidos, que recepta el escrutinio de Penn Central (USSC, Penn Central Station Co. v. New York City, 438 U.S. 104, 1978) -impacto económico de la medida, nivel de interferencia de la regulación con expectativas razonables y carácter de la acción gubernamental- y le aporta dos precisiones fundamentales: primero, el sólo hecho del efecto adverso que una medida pueda tener en el valor económico de una inversión no comporta, per se, una expropiación indirecta (ello parece oponerse al criterio arbitral que sólo toma como referencia la afectación del inversor); segundo, adiciona a los tres factores de Penn Central el siguiente: Salvo en raras ocasiones, las medidas regulatorias de una Parte que no resulten discriminatorias y se encuentren orientadas a la protección de objetivos legítimos de bienestar general, tales como salud pública, seguridad o ambiente, no constituyen expropiación indirecta. La alusión al carácter no discriminatorio de la medida como guía para discernir el derecho a una indemnización confirma la gravitación que posee ese extremo si queremos evitar la obturación de todo avance jurídico en el país receptor. Sobre los principios regulatorios y su incidencia en los arbitrajes de inversión, véase Bohoslavsky, cit.

64 Una importante muestra de la convergencia de los sistemas de protección de los derechos humanos y el derecho de inversiones puede verse en el caso Yukos (STEDH, OAO Neftyanaya Kompaniya Yukos v. Rusia, 20 de septiembre de 2011 y 31 de julio de 2014; UNCITRAL, Yukos Universal Limited (Isla de Man) v. Federación Rusa, Caso No AA 227, 18 de julio de 2014). 
explicitados -desviación de poder-o bien; iv) es adoptada con manifiesto desprecio del debido proceso ${ }^{65}$. Resulta fundamental, así, evaluar la existencia de motivaciones persecutorias o sacrificio especial.

Es que, en la medida en que la regulación constituye en la actualidad un aspecto natural del entorno en el cual cualquier empresa debe desenvolverse, resulta incorrecto partir de la posibilidad de reclamar indemnización cada vez que una decisión gubernamental afecta negativamente el valor de su inversión. Este es el punto central de la incorrección de la lectura tradicional de las cláusulas de expropiación de los TBIs: Una vez que se reconoce que cualquier regulación puede implicar cambio negativo en el valor de una inversión, la existencia de la pérdida económica por sí no alcanza para sí sola para funcionar como sustento de la obligación de indemnizar. Es necesario que se configure un desequilibrio en la distribución de los costos de la medida en perjuicio del inversor.

El abordaje ortodoxo de la expropiación, con su énfasis en la privación que sufre el empresario y la ausencia de referencia a los fines y alcances de la medida estatal, se traduce en el deber de no regular sin compensar. Al hacer caso omiso de la evolución del papel de Estado como regulador, la exigencia de una reparación monetaria por cualquier privación causada por el gobierno transforma a los TBIs en pólizas de seguro contra el riesgo regulatorio ${ }^{66}$.

A la luz de lo dicho, las salvaguardas de trato justo y equitativo y expropiación se tornan operativas sólo ante conductas discriminatorias, pero no habilitan reclamos de los inversores por cambios legislativos generales que afecten a toda la población. De admitirse ese criterio, esas garantías se verían asimiladas a las cláusulas de estabilización y ello implicaría contrariar la interpretación restrictiva que corresponde seguir en materia de privilegios a favor de los inversores. Dicho de otro modo, trato justo y equitativo es ausencia de hostilidad pero no inalterabilidad, ausencia de riesgo o paternalismo, mientras que expropiación indirecta presupone sacrificio especial pero no asegura inmunidad frente a cambios regulatorios de carácter general.

\subsection{Interpretación evolutiva y estabilización en el campo de los TBIs. El caso de las comunidades indígenas}

Una última muestra de la pugna entre una interpretación que prioriza excesivamente la estabilidad del entorno de la inversión y la necesidad de progresar diariamente para alcanzar las metas que fijan los pactos de derechos humanos, se advierte en la eventual colisión del TJE y las cláusulas de estabilización con el principio de consentimiento previo,

65 Toto Costruzioni Generali S.p.A, supra nota 51, párr. 157.

66 Véase, SATTOROVA, Op. cit. 
libre e informado de las comunidades indígenas para el desarrollo de proyectos productivos en sus territorios.

El tratamiento de la situación de las comunidades indígenas a lo largo del continente americano y la incidencia de los estándares de derechos humanos en la gestión de los recursos naturales es uno de los aspectos más salientes de la reciente evolución de esta rama del derecho internacional.

El punto de partida de esa evolución es el reconocimiento dela noción de territorialidad indígena. Se entiende por territorialidad al modo de conceptualizar y de apropiar el espacio social en que se vive; se reflejan en ella las distintas formas de relación con la naturaleza instituidas por los grupos sociales que ocupan la tierra. El territorio es, desde esa perspectiva, una construcción social realizada en forma consciente por grupos humanos que objetivizan su relación con el ambiente a través de prácticas continuas. Se trata de una construcción colectiva, y su reflejo más patente es la presencia de una estructura social tradicional, bien definida, que habita el espacio mediante representaciones culturales, a partir de ritos asociados a la tierra, ordenando religiosamente su entorno.

En función de esas características, la Corte Interamericana de Derechos Humanos ha destacado que los derechos territoriales indígenas abarcan un concepto más amplio y diferente de la simple posesión de un bien, que está relacionado con el derecho colectivo a la supervivencia como pueblo organizado, con el control de su hábitat como una condición necesaria para la reproducción de su cultura, para su propio desarrollo y para llevar a cabo sus planes de vida. Dada su importancia, la noción de territorialidad indígena juega hoy un rol clave en la relación con los titulares de derechos que involucran a comunidades originarias, en la medida en que confiere un plus de protección a éstas últimas en caso de conflicto con derechos civiles de propiedad ${ }^{67}$.

En ese marco, se ha desarrollado y se consolidado a nivel internacional la exigencia del consentimiento previo, libre e informado de las comunidades indígenas en relación a los proyectos de explotación de los recursos naturales existentes en sus tierras, lo cual constituye

67 En efecto, la Corte Interamericana ha señalado que "para las comunidades indígenas la relación con la tierra no es meramente una cuestión de posesión y producción sino un elemento material y espiritual del que deben gozar plenamente, inclusive para preservar su legado cultural y transmitirlo a las generaciones futuras" (Corte IDH, Caso de la Comunidad Mayagna (Sumo) Awas Tingni v. Nicaragua. Fondo, Reparaciones y Costas, 31 de agosto de 2001, párr. 148) y que "la cultura de los miembros de las comunidades indígenas corresponde a una forma de vida particular de ser, ver y actuar en el mundo, constituido a partir de su estrecha relación con sus territorios tradicionales y los recursos que allí se encuentran, no sólo por ser éstos su principal medio de subsistencia, sino además porque constituyen un elemento integrante de su cosmovisión, religiosidad y, por ende, de su identidad cultural" (Corte IDH, Caso Comunidad indígena Yakye Axa v. Paraguay. Fondo, Reparaciones y Costas, 17 de junio de 2005, párr. 142 y ss.). 
un límite decisivo a los derechos reconocidos por el Estado sobre esos recursos.

La Corte Interamericana receptó la noción en el Caso del Pueblo Saramaka v. Surinam, de 2007, estableciendo el triple estándar de consulta $y$ consentimiento, estudios de impacto y participación en los beneficios como requisito para la validez de emprendimientos productivos en los territorios de las comunidades.

En ese caso, el ordenamiento doméstico de Surinam solamente garantizaba a la comunidad el derecho al uso de la tierra, pero no aseguraba el derecho a controlar efectivamente el territorio sin injerencias externas. Los principales perjuicios provenían de concesiones mineras y forestales a terceros que claramente ponían en riesgo la integridad de las tierras de los Saramaka. Por ello la Corte enfatizó que el derecho de propiedad de ese pueblo implicaba la previa delimitación de las tierras como paso para el otorgamiento de un título legal de propiedad que conlleve la posibilidad de uso de los recursos naturales, especialmente porque de ello depende la preservación del estilo de vida propio de ese pueblo.

En ese marco, la Corte estableció que el respeto del art. 21 de la Convención Americana -que consagra el derecho de las personas al uso y goce de sus bienes- en relación con los pueblos indígenas demanda siempre la efectiva participación de la comunidad, de acuerdo a sus costumbres y tradiciones, respecto de cualquier plan de desarrollo, inversión, exploración o explotación que pretenda realizarse en su territorio. Esta obligación implica que el Estado debe aceptar y divulgar información, que las consultas deben ser de buena fe, por medio de procedimientos culturalmente adecuados y con el objetivo de alcanzar el consenso. Además, la consulta debe hacerse efectiva desde el primer momento de elaboración del proyecto y teniendo en cuenta los métodos propios de la comunidad para la toma de decisiones, especialmente el tiempo que ellos puedan insumir. El gobierno también debe garantizar que la comunidad conozca fehacientemente los riesgos involucrados, tanto para la salud como el ambiente.

Adicionalmente, en aquellos emprendimientos que impliquen un mayor impacto en el territorio, el gobierno no sólo debe consultar a la comunidad, sino obtener su consentimiento libre, previo e informado. La mera consulta es insuficiente en estos casos. En segundo lugar, el Estado debe garantizar que la comunidad reciba un beneficio o rentabilidad razonable de cualquier emprendimiento en su territorio ${ }^{68}$. Tercero,

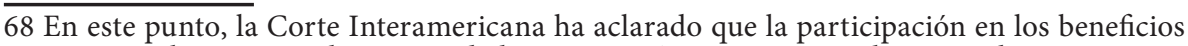
encuentra cobertura en el art. 21.2 de la Convención Americana sobre Derechos Humanos, pues la compensación que la misma impone no se limita a los supuestos de privación total de la propiedad por medio de la expropiación, sino también a la privación del uso regular y disfrute de tal propiedad. En ese contexto, el derecho a una justa indemnización se traslada al derecho de los miembros de la comunidad de participar razonablemente en los beneficios que resultan 
el Estado debe garantizar que ninguna concesión será otorgada en territorio de la comunidad a menos y hasta que entidades independientes e idóneas técnicamente, bajo la supervisión estatal, ejecuten un estudio previo de impacto ambiental y social.

En función de lo dicho, toda concesión administrativa de derechos de explotación sobre los recursos naturales que no cumpla estos tres requisitos configura una violación a los arts. 21 y 1.1 de la Convención Americana ${ }^{69}$.

El triple estándar fijado por la Corte Interamericana en el caso Saramaka (consulta y consentimiento; estudios de impacto; y participación en los beneficios) es aplicable, en los términos de la Corte, a "los planes de inversión, desarrollo, exploración o explotación de los recursos naturales" que puedan afectar de forma directa o indirecta la capacidad de los pueblos indígenas para usar y gozar efectivamente sus tierras, territorios y recursos naturales, de manera que supongan, de hecho, una privación o limitación de su derecho de propiedad"70.

Con ese alcance, la consagración de este estándar de trato plantea interrogantes en punto a su consistencia conlos derechos delos inversores. Baste pensar en la gran cantidad de derechos otorgados por el Estado sobre recursos ubicados en territorios indígenas y las implicancias que tiene reconocer capacidad de incidencia y de participación económica a esas comunidades.

La gradual adecuación del derecho doméstico al estándar comentado podría ser fuente de perjuicios económicos para inversores, quienes podrían aducir la existencia de una alteración sustantiva del marco jurídico existente al momento de reconocer su derecho a la explotación del recurso, que no incluía el deber de recabar el consentimiento de las comunidades y descansaba en la soberanía estatal sobre sus recursos. La situación se complejiza en caso de cláusulas de estabilización previas a la consagración de este criterio, que podrían pretender ser invocadas por las empresas para inmunizarse ante los

\footnotetext{
de la restricción o privación de su derecho al uso y goce de sus tierras tradicionales y de los recursos necesarios para su subsistencia.

69 En la misma línea, el art. 18 de la Declaración Universal de los Derechos de los Pueblos Indígenas reconoce a esos pueblos el derecho a participar en la adopción de decisiones en las cuestiones que afecten a sus derechos, por conducto de representantes elegidos por ellos de conformidad con sus propios procedimientos, así como a mantener y desarrollar sus propias instituciones de adopción de decisiones. Adicionalmente, el art. 32 de esa Declaración establece que los pueblos indígenas tienen derecho a determinar y elaborar las prioridades y estrategias para el desarrollo o la utilización de sus tierras o territorios y otros recursos y que los Estados deben celebrar consultas y cooperar de buena fe con los pueblos indígenas interesados por conducto de sus propias instituciones representativas "a fin de obtener su consentimiento libre e informado antes de aprobar cualquier proyecto que afecte a sus tierras o territorios y otros recursos, particularmente en relación con el desarrollo, la utilización o la explotación de recursos minerales, hídricos o de otro tipo".

70 Corte IDH, Caso del Pueblo Saramaka v. Surinam. Excepciones Preliminares, Fondo, Reparaciones y Costas, 28 de noviembre de 2007, párr. 129.
} 
cambios en el derecho doméstico que él implica.

Estos interrogantes, nuevamente, deben ser resueltos de un modo que permita conjugar la tutela del inversor contra tratos discriminatorios, pero que computen necesariamente la naturaleza dinámica y evolutiva que es propia de los derechos humanos.

\section{CONCLUSIONES}

Tanto los tratados de derechos humanos como los de protección de inversiones involucran opciones políticas que generan consecuencias distributivas a lo largo del tiempo. La decisión de concluir un TBI constituye un compromiso social y económico que vincula al Estado y sus recursos en la protección de la inversión extranjera a través de un conjunto de estándares de tratamiento durante la vida de la inversión ${ }^{71}$. Esa determinación no puede efectuarse sin tomar en consideración la necesidad de adecuar de modo dinámico y evolutivo el funcionamiento del marco jurídico y económico de un modo que permita cumplir con las obligaciones de respeto, garantía y protección de los derechos humanos, mientras se garantiza un mínimo espacio fiscal a ese mismo Estado que aloja la inversión de manera que se facilite la implementación de estrategias nacionales de desarrollo.

Siendo ello así, los inversores no pueden pretender que los compromisos plasmados en los TBIs obturen esa adecuación. Antes bien, la debida diligencia en la determinación del entorno jurídico, económico y social del país en el cual desean invertir, necesariamente debe incluir un diagnóstico sobre el nivel de cumplimiento estatal en materia de derechos humanos y las medidas que son razonablemente esperables para la mejora progresiva de su desempeño en ese campo. A la luz del robusto desarrollo de los derechos humanos en el campo empresarial, tal como lo demuestra creciente implementación de los Principios Rectores de las Naciones Unidas sobre Empresas y Derechos Humanos, los inversores no pueden permanecer ajenos a las externalidades de sus acciones (y omisiones) en materia de derechos humanos.

La evolución en el sistema de protección de inversiones de las últimas décadas permite advertir una fuerte expansión de las garantías a favor de los inversores a través de una ampliación de las conductas consideradas como violatorias de los estándares contenidos en ellos. No sólo los parámetros de protección han recibido una interpretación amplia, sino que se ha admitido que sean mutuamente intercambiables de un modo que deriva en una segura condena arbitral. La fusión de los principios de los TBIs en una red de protección vasta y elástica

71 Véase SIMMA, Bruno y DESIERTO, Diane. "Bridging the Public Interest Divide: Committee assistance for investor-host State compliance with the ICESCR". Transnational Dispute Management (TDM). 2013, vol 10. 
transforma el régimen de inversión moderno en uno en el que el mero hecho del impacto económico negativo de la conducta gubernamental en la inversión puede ser suficiente para responsabilizar al Estado receptor.

Mientras que ese resultado ha derivado en una creciente crisis de legitimidad del régimen de los TBIs, pronunciamientos más recientes, como el de El Paso, permiten ser optimistas en que se alcance una fórmula más equilibrada entre la necesidad de resguardar a los inversores extranjeros contra actos arbitrarios o discriminatorios y la de no obturar el ejercicio de las potestades públicas, en tanto vehículos imprescindibles para la vigencia de los derechos humanos. El logro de ese equilibrio depende hoy de un mayor diálogo entre los cuerpos y tribunales $^{72}$ involucrados en la resolución de ese tipo de asuntos (sobre inversiones por un lado y derechos humanos por el otro) que permita forjar un mayor grado de consistencia y sustentabilidad en el derecho internacional y las obligaciones que éste impone a los Estados ${ }^{73}$.

\section{REFERENCIAS BIBLIOGRÁFICAS}

BILCHITZ, David. "The Ruggie Framework: an Adequate Rubric for Corporate Human Rights Obligations?”. Sur International Journal on Human Rights. 2010, vol 7, n 12.

BLITT, Robert C. "Beyond Ruggie's Guiding Principles on Business and Human Rights: Charting an Embracive Approach to Corporate Human Rights Compliance". University of Tennessee Legal Studies Research Paper. $2011, n^{\circ} 158$.

BOHOSLAVSKY, Juan Pablo. Tratados de protección de las inversiones e implicaciones para la formulación de políticas públicas (especial referencia a los servicios de agua potable y saneamiento). s.l: CEPAL, 2010.

BOHOSLAVSKY, Juan Pablo y JUSTO, Juan Bautista. "The Conventionality Control of Investment Arbitrations: Enhancing Coherence through Dialogue". Transnational Dispute Management Journal (TDM). 2013, vol 1.

BURKE-WHITE, William. "International Legal Pluralism". Michigan Journal of International Law. 2004, vol 25, p. 978.

COTULA, Lorenzo. Foreign investment contracts. ciudad: International Institute for Environment and Development, 2007.

DAVITTI, Daria. "On the Meanings of International Investment Law and International Human Rights Law: The Alternative Narrative of Due Diligence". Human Rights Law Review. 2012, vol 12, n 3.

DESIERTO, Diane. "Sovereign Policy Flexibility for Social Protection:

72 Véase DUPUY, Pierre-Marie y VIÑUALES, Jorge. "The Challenge of "Proliferation": An Anatomy of the Debate". En: ROMANO, Cesare; ALTER, Karen y SHANY, Yuval (ed). The Oxford Handbook of International Adjudication. Oxford: Oxford University Press, 2014.

73 BURKE-WHITE, William. "International Legal Pluralism". Michigan Journal of International Law. 2004, vol 25, p. 978. 
Managing Regulatory Risk in IIAs. Mauritius International Arbitration Conference. 2012.

DUPUY, Pierre-Marie y VIÑUALES, Jorge. "The Challenge of "Proliferation": An Anatomy of the Debate". En: ROMANO, Cesare; ALTER, Karen y SHANY, Yuval (ed). The Oxford Handbook of International Adjudication. Oxford: Oxford University Press, 2014.

GARCÍA DE ENTERRÍA, Eduardo. "El principio de confianza legítima como supuesto título justificativo de la responsabilidad patrimonial del Estado legislador". Revista de Administración Pública. 2002, nº 159.

JACOB, Marc. "International investment agreements and human rights". INEF Research PaperSeries Human Rights, 2010, nº 3 .

KAUSHAL, Asha. "Revisiting history: how the past matters for the present backlash against the foreign investment regime". Harvard International Law Journal. 2009, vol 50, $\mathrm{n}^{\circ} 2$.

LEADER, Sheldon. "Human Rights, Risks, and New Strategies for Global Investment”. Journal of International Economic Law. 2006, vol 9, $\mathrm{n}^{\circ} 3$.

MONTT, Santiago. "What international investment law and Latin America can and should demand from each other. Updating the Bello/ Calvo doctrine in the BIT generation". En: AA.VV. (ed). El Nuevo Derecho Administrativo Global en América Latina.Buenos Aires, 2009. OCDE. "Indirect Expropriation" and the "Right to Regulate". In: International Investment Law. OECD Working Papers on International Investment. 2004/04, p. 3.

ONU. Consejo de Derechos Humanos. Principios Rectores sobre Empresas y Derechos Humanos. Proteger, Respetar y Remediar (A/HRC/ RES/17/4, 16 de junio de 2011.

SATTOROVA, Mavluda. "Investment Treaty Breach as Internationally Proscribed Conduct: Shifting Scope, Evolving Objectives, Recalibrated Remedies?". Trade Law \& Development.2012, vol 4, no 2.

SIMMA, Bruno y DESIERTO, Diane. "Bridging the Public Interest Divide: Committee assistance for investor-host State compliance with the ICESCR". Transnational Dispute Management (TDM). 2013, vol 10. UNCTAD. Trade and Development Report. Ginebra: UNCTAD, 2014. UNCTAD. Fair and Equitable Treatment. Ginebra: Naciones Unidas. 2012. 